\section{Response of an Orchardgrass-Subclover Mixture In Western Oregon to Different Clipping And Fertilizing Practices ${ }^{1}$}

DONALD W. HEDRICK

Professor of Range Management, Oregon State University, Corvallis, Oregon.2

\section{Introduction}

Considerable attention in both California and Oregon has been directed toward establishment of subterranean clover (Trifolium subterraneum L.), usually referred to as subclover (Williams et al., 1957; McGuire, 1961). Few

${ }^{1}$ Technical Paper No. 1724 from the Oregon Agricultural Experiment Station.

2 Assistance and Counsel of Dr. T. L. Jackson, Prof. of Soils at O.S.U. is acknowledged. studies in the United States, however, have been concerned with management of established stands. Most of the work undertaken in the United States on grass-legume mixtures has been with white clover (Trifolium repens L.) and trefoil (Lotus spp.) with various grasses, e.g., Austenson and Law, (1955) and Davis and Bell, (1957). A number of studies on subcloverperennial grass management have been made in Australia. For example, Andrew, (1960) has in- dicated the necessity of keeping grass rows fairly widely spaced for maximum production; otherwise not enough underground transfer of nitrogen from the subclover is obtained to keep the grass growing vigorously.

In view of this need for information on management of established stands in western Oregon, a 5-year study was undertaken in the Willamette Valley to better assess the influence of various fertilizer and cutting practices on the production of an orchardgrass (Dactylis glomerata L.)-subclover mixture. Common orchardgrass and Nangeela subclover were the varieties used in this experiment. Subclover is a winter annual that germinates with the first substantial rain $(0.5$ inch or more followed by several cloudy days) in September. Growth of 
this mixture during October and November depends upon favorable moisture and temperature but is generally negligible from December through March. The main growth period extends from April through June.

The study area occupies a transition zone between the oak woodlands of the hills and the valley bottoms used intensively for crop production. Although many of the soils are cultivated, the best land use is improved pasture. When used as improved pasture without irrigation, a grass-legume mixture with subclover probably supplies a maximum amount of forage. However, many such mixtures have not been maintained because of failure to manage them properly (Figure 1). It is recognized that cutting does not simulate grazing directly, but some of the effects are similar, particularly in relationship to light, which appears to be a critical factor in management of subclover in mixtures with grass.

\section{Materials and Methods}

Soil in the study area has been described by Carpenter and Torgerson (1924). It is Grande
Ronde silty clay loam which occupies terraces and alluvial slopes and is derived mainly from water-laid deposits having their source in the sandstone or shale rocks of the adjacent hills. It occupies a position intermediate between the lower alluvial soils of the valley and the residual soils of the hills. The topography is gently sloping to undulating and surface drainage is usually good, though subsoil drainage is restricted. Seepage from the hills often keeps these soils wet until late in the spring.

The surface soil of the Grande Ronde silty clay loam has an average depth of 14 inches and consists of a yellowish-brown smooth-textured silty clay loam, low in organic matter. The subsoil, to a depth of 22 inches, consists of yellowish-brown silty clay, mottled with gray or yellow. The lower subsoil is a brownish-yellow clay, mottled with gray and sometimes with iron stains. Soil test samples from the 0 to 6 -inch layer were taken to evaluate $\mathrm{pH}$, phosphorus, potassium, calcium, magnesium and cation exchange capacity. Phosphorus was determined using sodium bicarbonate

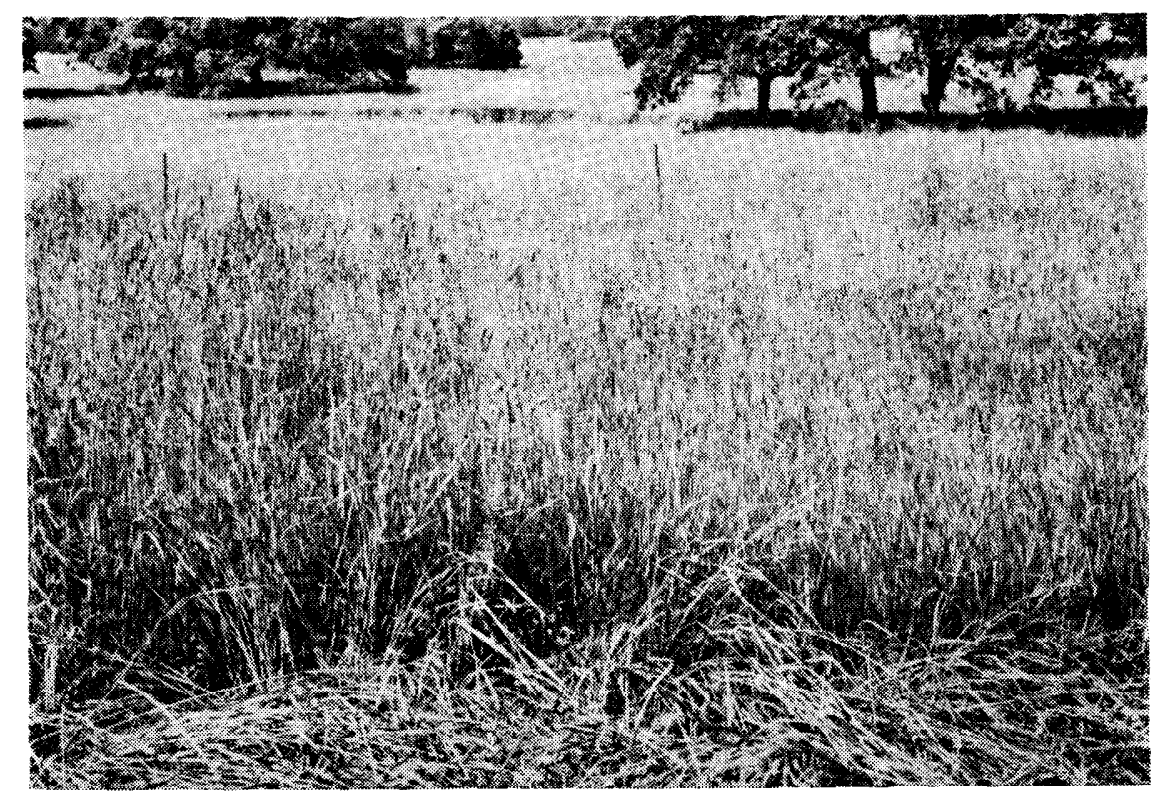

Ficure 1. General view of experimental area. Plot on right received $80 \mathrm{lbs}$. of nitrogen per acre annually but produced less forage than plot on left without nitrogen but with a good stand of subclover. extract; exchangeable bases were extracted with $1 \mathrm{~N}$ ammonium acetate using procedures outlined by Alban and Kellogg (1959). Duplicate analyses on two different samples revealed ranges in each constituent except for $\mathrm{pH}$ as follows: $\mathrm{pH}$ 5.3; $\mathrm{P}$ (ppm 3.0-4.0) ; the remaining all in M.E./100 g: $\mathrm{K}(0.66-$ 0.82), $\mathrm{Ca}(6.4-6.8), \quad \mathrm{Mg}(3.5-4.1)$ and Cation Exchange Capacity (19.1-20.3). Phosphorus was judged to be the only nutrient deficient for legume growth and no lime was added to the experimental area even though the $\mathrm{pH}$ is on the low side for maximum growth of subclover.

The climate of this area has been designated as a mild-subcoastal type with moist, open winters, cool, dry summers and a dry harvest period. Extremes of temperature generally range from $20^{\circ} \mathrm{F}$ to $90^{\circ} \mathrm{F}$ between winter and summer with only brief periods down to $10^{\circ} \mathrm{F}$ or up to $100^{\circ} \mathrm{F}$. Maximum temperatures generally occur in August and minimums in January. Heaviest precipitation occurs from November through January and snowfall averages less than six inches annually. July and August are typically dry and rainfall averages less than two inches in the months of May, June and September. Low temperatures generally limit grass and legume growth to slow accumulation of foliage from about November 1 to March 1, and insufficient precipitation restricts forage production from mid-June through September.

The weather during the course of the experiment was remarkably consistent. Selected data on temperature and precipitation for the period 1956 through 1960 are included in Table 1. Crop year precipitation was above average in 1955-56 and below in 1956-57 and 1959-60, whereas figures for 1957-58 and 1958-59 were about normal. The precipitation and temperature figures from 
Table 1. Selected weather data for Corvallis, 1955-60.

Mean temperatures (F) and precipitation (inches) by months during spring growing period each year of the experiment

\begin{tabular}{|c|c|c|c|c|c|c|c|c|c|c|}
\hline \multirow[b]{2}{*}{ Month } & \multicolumn{2}{|c|}{1956} & \multicolumn{2}{|c|}{1957} & \multicolumn{2}{|c|}{1958} & \multicolumn{2}{|c|}{1959} & \multicolumn{2}{|c|}{1960} \\
\hline & $\begin{array}{l}\text { Mean } \\
\text { Temp. }\end{array}$ & Ppt. & $\begin{array}{l}\text { Mean } \\
\text { Temp. }\end{array}$ & Ppt. & $\begin{array}{l}\text { Mean } \\
\text { Temp. }\end{array}$ & Ppt. & $\begin{array}{l}\text { Mean } \\
\text { Temp. }\end{array}$ & Ppt. & $\begin{array}{l}\text { Mean } \\
\text { Temp. }\end{array}$ & Ppt. \\
\hline March & 43.30 & 5.89 & 46.33 & 7.01 & 44.26 & 2.55 & 45.06 & 3.99 & 44.55 & 7.18 \\
\hline April & 50.58 & .93 & 50.95 & 2.11 & 49.71 & 3.66 & 50.2 & .84 & 49.5 & 3.29 \\
\hline May & 57.18 & 1.98 & 57.47 & 3.21 & 59.85 & 1.12 & 53.1 & 2.20 & 52.34 & 3.92 \\
\hline June & 57.60 & 1.14 & 61.20 & 1.07 & 63.64 & 2.91 & 60.3 & 1.31 & 61.54 & .22 \\
\hline
\end{tabular}

Mean temperature and total precipitation by crop years

\begin{tabular}{|c|c|c|c|c|c|c|c|c|c|c|}
\hline & \multicolumn{2}{|c|}{$(1955-56)$} & \multicolumn{2}{|c|}{$(1956-57)$} & \multicolumn{2}{|c|}{$(1957-58)$} & \multicolumn{2}{|c|}{$(1958-59)$} & \multicolumn{2}{|c|}{$(1959-60)$} \\
\hline & Temp. & Ppt. & Temp. & Ppt. & Temp. & Ppt. & Temp. & Ppt. & Temp. & Ppt. \\
\hline $\begin{array}{l}\text { September } \\
\text { through June }\end{array}$ & 48.10 & 56.12 & 48.29 & 33.99 & 50.47 & 44.03 & 49.99 & 40.04 & 48.35 & 34.58 \\
\hline
\end{tabular}

March through June are more important than the totals. Based on the seasonal distribution it appears that the 1958-59 growing season may have been slightly deficient with a total spring precipitation of eight plus inches compared with 10 or more in other years. Otherwise, weather was probably not an important variable during the five-year period of the experiment.

The experimental design consisted of an incomplete factorial with six treatments (Table 2). To a complete factorial of four factors $(2 \times 4 \times 2 \times 2)$ or a total of 32 treatments, ten more were added in the third management system (fall and mid-spring and June) in the form of: (1) a check plot; (2) and (3), two levels each of sulfur ( 0 and 40 lbs/acre) and phosphorus ( 0 and $100 \mathrm{lbs} \mathrm{P}_{2} \mathrm{O}_{5} /$ acre) ; and (4) and (5), the third level of nitrogen applied in both fall and spring. Each of these five treatments was applied on a set of plots cut at both the 2 and 3 -inch stubble heights. These 42 treatments were completely randomized in each of four blocks or replications.

The study area was seeded in the fall of 1955 after summer fallowing to control a stand of Astoria bentgrass (Agrostis tenuis
Sibth) which had occupied the site since 1943. In June of 1956 , two square-foot random samples in each treatment plot of $5 \times 15$ feet were clipped at a 2-inch height as a pre-treatment inventory of production and composition. Afterwards, the area was uniformly mowed to a 2-inch stubble height and fertilizer and clipping treatments were started

in the fall (October 1) of 1956. Periodic harvests were taken from each plot with the use of the Scythette (Hedrick and Hitchcock, 1953) during 1957, 1958 and 1959. In June, 1960, all plots were sampled by clipping another two, 1-sq.-foot samples from each treatment at a 2 -inch height for comparison with the 1956 figures.

Table 2. Arrangement of treatments in subclover management experiment. Management Systems with:

\begin{tabular}{|c|c|c|c|c|c|c|c|c|}
\hline \multirow{4}{*}{$\begin{array}{l}\text { Height } \\
\text { of } \\
\text { Cutting } \\
\text { (Inches) }\end{array}$} & \multicolumn{4}{|c|}{ Dates of Cutting } & \multirow{2}{*}{\multicolumn{4}{|c|}{$\begin{array}{c}\text { Fertilizer Treatment } \\
\text { lbs./A of }\end{array}$}} \\
\hline & \multirow{3}{*}{$\begin{array}{cc}1 \\
\text { Oct. } 1 \\
\text { Apr. } 1 \\
\text { May } 1\end{array}$} & \multirow{3}{*}{$\begin{array}{c}2 \\
\text { Apr. } 1 \\
\text { June } 1\end{array}$} & \multirow{3}{*}{$\begin{array}{cc}3 \\
\text { Oct. } & 1 \\
\text { May } & 1 \\
\text { Jun. } & 1\end{array}$} & \multirow{3}{*}{$\begin{array}{c}4 \\
\text { Aug. } 1 \\
\text { May } 1\end{array}$} & & & & \\
\hline & & & & & \multicolumn{2}{|c|}{ Nitrogen } & \multirow[t]{2}{*}{$\underline{s}$} & \multirow[t]{2}{*}{$\mathrm{P}_{2} \mathrm{O}_{5}$} \\
\hline & & & & & Fall & Spring & & \\
\hline 2 & $x$ & $\mathbf{x}$ & $\mathrm{x}$ & $\mathrm{x}$ & 0 & 0 & 40 & 100 \\
\hline 3 & $x$ & $x$ & $x$ & $x$ & & & & \\
\hline 2 & $x$ & $\mathrm{x}$ & $x$ & $\mathrm{x}$ & 40 & 0 & 40 & 100 \\
\hline 3 & $\mathrm{x}$ & $x$ & $x$ & $\mathrm{x}$ & & & & \\
\hline 2 & $x$ & $\mathrm{x}$ & $x$ & $x$ & 0 & 40 & 40 & 100 \\
\hline 3 & $x$ & $\mathrm{x}$ & $x$ & $\mathrm{x}$ & & & & \\
\hline 2 & $\mathbf{x}$ & $\mathrm{x}$ & $x$ & $x$ & 40 & 40 & 40 & 100 \\
\hline 3 & $x$ & $\mathrm{x}$ & $\mathrm{x}$ & $\mathrm{x}$ & & & & \\
\hline 2 & & & $\mathrm{x}$ & & 0 & 0 & 0 & 0 \\
\hline 3 & & & $\mathrm{x}$ & & & & & \\
\hline 2 & & & $x$ & & 0 & 0 & 40 & 0 \\
\hline 3 & & & $\mathrm{x}$ & & & & & \\
\hline 2 & & & $\mathbf{x}$ & & 0 & 0 & 0 & 100 \\
\hline 3 & & & $\mathbf{x}$ & & & & & \\
\hline 2 & & & $x$ & & 80 & 0 & 40 & 100 \\
\hline 3 & & & $x$ & & & & & \\
\hline 2 & & & $x$ & & 0 & 80 & 40 & 100 \\
\hline 3 & & & $\mathrm{x}$ & & & & & \\
\hline
\end{tabular}


Table 3. Dry weight yields1: means over all years by treatments.

\begin{tabular}{|c|c|c|c|c|c|c|c|c|c|}
\hline $\begin{array}{l}\text { Height } \\
\text { of } \\
\text { Clipping2 }\end{array}$ & No. & $\begin{array}{c}\text { Management System }{ }^{3} \\
\text { Dates of Cutting }\end{array}$ & & 0 & Fall I & ogen $^{2}$ & lbs/ & & Ht. x Mgt. \\
\hline \multirow[b]{2}{*}{$2^{\prime \prime}$} & & & $\begin{array}{l}\text { Spring } \\
0\end{array}$ & $\begin{array}{c}\mathrm{N} \\
40\end{array}$ & Means & $\begin{array}{c}\text { Spring } \\
0\end{array}$ & $\begin{array}{l}\mathrm{N} \\
40\end{array}$ & Means & Means \\
\hline & $\begin{array}{l}1 \\
2 \\
3 \\
4\end{array}$ & $\begin{array}{l}\text { Oct. 1, April 1, May } 1 \\
\text { April } 1 \text { and June } 1 \\
\text { Oct. 1, May 1, June } 1 \\
\text { May - and August } 1 \\
\quad \text { Means }\end{array}$ & $\begin{array}{l}-1-- \\
284 \\
377 \\
430 \\
467 \\
390\end{array}$ & $\begin{array}{l}-- \\
466 \\
594 \\
456 \\
565 \\
509\end{array}$ & $\begin{array}{l}-1- \\
375 \\
463 \\
443 \\
516 \\
449\end{array}$ & $\begin{array}{l}\text { Grams) } \\
410 \\
488 \\
442 \\
541 \\
470\end{array}$ & $\begin{array}{l}- \\
589 \\
693 \\
553 \\
644 \\
620\end{array}$ & $\begin{array}{l}-799 \\
590 \\
497 \\
593 \\
545\end{array}$ & $\begin{array}{r}-\overline{437} \\
527 \\
470 \\
554 \\
497\end{array}$ \\
\hline $3^{\prime \prime}$ & $\begin{array}{l}1 \\
2 \\
3 \\
4\end{array}$ & $\begin{array}{l}\text { Oct. 1, April 1, May } 1 \\
\text { April } 1 \text { and June } 1 \\
\text { Oct. } 1 \text {, May 1, June } 1 \\
\text { May } 1 \text { and August } 1 \\
\quad \text { Means } \\
\text { N Treatment Means }\end{array}$ & $\begin{array}{l}314 \\
377 \\
308 \\
370 \\
342 \\
366\end{array}$ & $\begin{array}{l}360 \\
524 \\
430 \\
487 \\
450 \\
480\end{array}$ & $\begin{array}{l}337 \\
450 \\
369 \\
428 \\
396 \\
423\end{array}$ & $\begin{array}{l}334 \\
403 \\
390 \\
531 \\
415 \\
442\end{array}$ & $\begin{array}{l}443 \\
638 \\
488 \\
580 \\
537 \\
579\end{array}$ & $\begin{array}{l}389 \\
521 \\
439 \\
555 \\
476 \\
510\end{array}$ & $\begin{array}{l}363 \\
486 \\
404 \\
492 \\
436 \\
467\end{array}$ \\
\hline
\end{tabular}

1Yields in grams per 19.2 sq. ft. plot.

2LSD at the .01 level is 26 grams for height and both fall and spring $\mathrm{N}$.

3 For management systems, LSD is 37 grams.

\section{Results}

Complete harvest data by plots were taken from 1957 through 1959 and analyzed to obtain the summary means; data in Table 3 are based on yields from plots receiving blanket applications of phosphorus and sulfur. Response to phosphorus was marked. This is indicated by significant yield differences (not reported in Table 3) in cutting treatment number 3 (October 1, May 1 and June 1) where check plots produced 295 grams versus 422 grams from plots receiving phosphorus. No response was obtained from additions of sulfur. Highly significant differences were obtained for replications, all treatments, and two interactions - management systems $x$ spring nitrogen and years $x$ treatment. As expected, highest yields were produced by 2 -inch clipping heights when cut only twice during the season. Although both fall and spring nitrogen applications increased production, spring treatments were more effective and generally had less of a depressive influence on the stands of subclover.

There were two different patterns of response to nitrogen fertilizer. Spring nitrogen on man- agement system No. 3 (cut Oct. 1 , May 1 and June 1) resulted in less increase than on the other three. Although the general pattern of yields was greatest the first year with nitrogen and remained about constant the second and third season, means of all management systems without nitrogen or with only spring applications at the 2-inch stubble height increased to their highest point the third and final season of clipping (Table 4).

Data in Table 5 support the conclusion that subclover is of value in supplying nitrogen to the grass since yields in 1960 were proportional to the percent of the subclover at the end of the experiment. This relationship between total yield and amount of subclover is best shown by the regression line in Figure 2. Wherever plots were harvested in June or August, subclover stands were maintained when clipped at the two-inch height even with 40 to $80 \mathrm{lbs}$. of nitrogen applied annually. Although yields from unfertilized plots showed a greater total yield increase per unit of subclover or more benefit from association with subclover, this influence was not pronounced except for management system No. 1 where the plots were not clipped during

Table 4. Influence of nitrogen fertilizer on mean production per plot of four management systems at two clipping heights for three years 195759.

\begin{tabular}{|c|c|c|c|c|c|c|}
\hline \multirow[b]{2}{*}{$\begin{array}{l}\text { Cutting } \\
\text { Height }\end{array}$} & \multirow[b]{2}{*}{ Year } & \multicolumn{2}{|c|}{ Fall Nitrogen 0} & \multicolumn{2}{|c|}{ Fall Nitrogen 40 lbs. } & \multirow[b]{2}{*}{ Means } \\
\hline & & $\begin{array}{l}\text { Spring } \\
0\end{array}$ & $\begin{array}{l}\text { Spring } \\
40 \text { lbs. }\end{array}$ & $\begin{array}{l}\text { Spring } \\
\quad 0\end{array}$ & $\begin{array}{l}\text { Spring } \\
40 \mathrm{lbs} \text {. }\end{array}$ & \\
\hline \multirow{4}{*}{$2^{\prime \prime}$} & & - & -- & (Grams) & -- & -1 \\
\hline & 1957 & 356 & 476 & 488 & 650 & 492 \\
\hline & 1958 & 370 & 500 & 481 & 596 & 487 \\
\hline & 1959 & 443 & 552 & 441 & 614 & 513 \\
\hline \multicolumn{2}{|c|}{$\begin{array}{c}\text { Percent Subclover } \\
1960\end{array}$} & 30.3 & 34.8 & 33.9 & 23.3 & 30.6 \\
\hline \multirow[t]{3}{*}{$3^{\prime \prime}$} & 1957 & 365 & 480 & 441 & 604 & 473 \\
\hline & 1958 & 324 & 414 & 419 & 489 & 412 \\
\hline & 1959 & 338 & 456 & 384 & 519 & 424 \\
\hline \multicolumn{2}{|c|}{$\begin{array}{c}\text { Percent Subclover } \\
1960\end{array}$} & 30.9 & 20.1 & 15.9 & 8.5 & 23.9 \\
\hline
\end{tabular}


Table 5. Yields in grams per plot by years, management systems and heights with percentage change in subclover from 1956 to 1960.

\begin{tabular}{|c|c|c|c|c|c|c|c|c|c|}
\hline \multirow[b]{3}{*}{ Cutting Height (inches) } & \multicolumn{8}{|c|}{ Management System } & \multirow{3}{*}{ Means } \\
\hline & \multicolumn{2}{|c|}{1} & \multicolumn{2}{|c|}{2} & \multicolumn{2}{|c|}{3} & \multicolumn{2}{|c|}{4} & \\
\hline & 2 & 3 & 2 & 3 & 2 & 3 & 2 & 3 & \\
\hline Starting Subclover (pct.) & 32 & 39 & 32 & 34 & 41 & 35 & 37 & 32 & 35 \\
\hline $1956^{1}$ & 456 & 518 & 499 & 495 & 460 & 486 & 523 & 443 & 485 \\
\hline 1957 & 426 & 403 & 511 & 538 & 466 & 453 & 567 & 496 & 482 \\
\hline 1958 & 406 & 349 & 524 & 463 & 494 & 390 & 522 & 444 & 449 \\
\hline 1959 & 480 & 336 & 545 & 455 & 451 & 369 & 574 & 536 & 468 \\
\hline $1960^{1}$ & 589 & 631 & 914 & 790 & 1135 & 989 & 920 & 627 & 825 \\
\hline Ending Subclover (pct.) & 8 & 3 & 33 & 18 & 42 & 31 & 41 & 23 & 25 \\
\hline
\end{tabular}

11956 and 1960 yields based on a single yield taken in early to mid-June 1956 and late June to early July 1960.

the summer. Regressions for two and three-inch heights were computed separately but correlations (fertilized, unfertilized, two-inch, three-inch) were not significantly different from the over-all relationship plotted in Figure 2.

Although many workers have found an advantage in the use of nitrogen fertilizer and certain clipping treatments to either advance or delay the normal time for peak forage production, data from this study are not encouraging to workers concerned with subclover and grass in the Willamette Valley. Figure 3 illustrates typical growth rates of forage in this experiment. When clipped to a 2-inch stubble

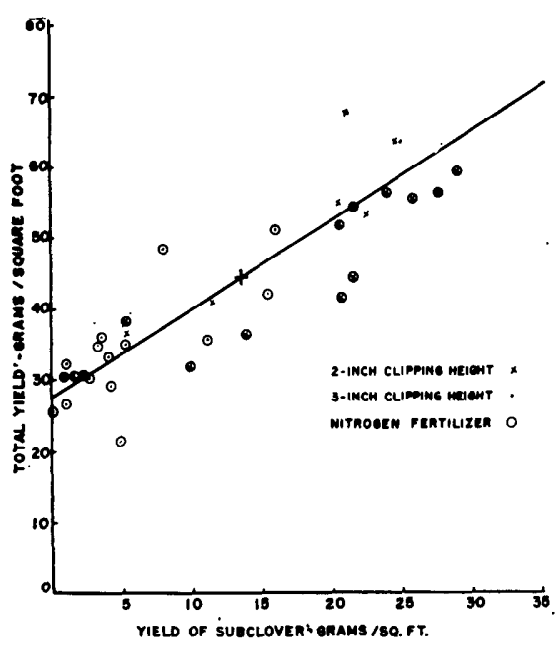

FigURE 2. Relationship between amount of subclover and total herbage yield expressed in grams of oven dry weight harvested from 1-square-foot plots in June, 1960.

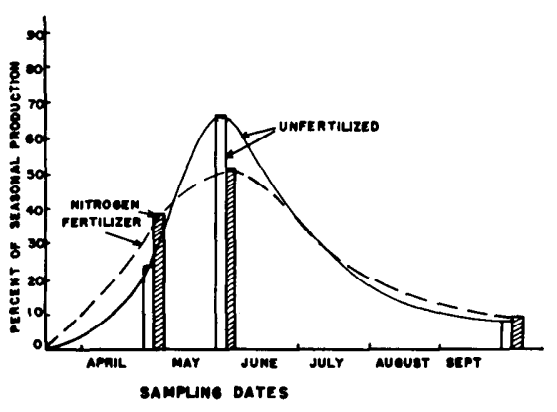

Figure 3. Influence of nitrogen fertilizer on percent seasonal production from management system clipped May 1, June 1 , and October 1 at 2 -inch stubble height.

height, approximately 10 percent of growth occurs before April 1 , 20 percent during April, about 60 percent in the month of May and 10 percent additional in June through September. Adjustments in fertilizer applications and time of cutting can influence the proportion of production in April and May but little, if any, effect can be made on forage produced before April 1, or after June 1. Maximum changes achieved in shifting the seasonal production in this trial resulted in raising the yield in April from one-fourth to two-fifths of the total and subsequently reducing May production from two-thirds to one-half.

In 1958 and 1959, samples from each harvest were analyzed for crude protein. Figure 4 summarizes these analyses during the grazing season from plots with and without nitrogen fertilizer. Maximum production of protein

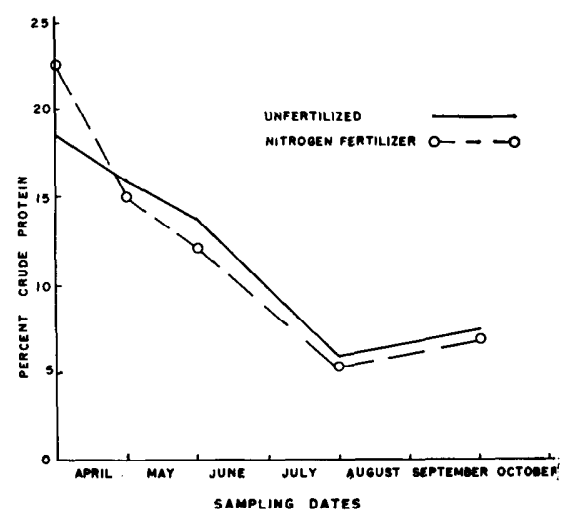

Figure 4. Influence of nitrogen fertilizer on crude protein content of bulk samples cut at 2 -inch stubble throughout grazing season.

occurrcd when stands were cut both in May and June and were not fertilized with nitrogen. Cutting only twice a year or once in the rapid growth period resulted in lower yields as well as indicating some response to nitrogen applications. At the 3 inch stubble height yields were highest from the same management system, but nitrogen responses were greater at this clipping level for all treatments.

\section{Application of Results in Grazing Management}

The value of subclover in the orchardgrass mixture used in this experiment is the same as that in any area where a legume is grown to maintain economical forage production. Subclover, if grown with suitable fertilizer amendments, furnished nitrogen indirectly to the associated grass and directly to livestock through its high nutritive content. In other words, grazing management to obtain the highest production from a grass-legume mixture must be directed toward maintaining a proper balance between the grass and legume components in the sward. A desirable composition for this mixture seems to range upward to 50 percent subclover. As a result of this study, several recommendations appear necessary in order to maintain a proper amount of 
subclover in a mixture with orchardgrass. These are: (1) Remove all material (both green and dry) from the areas sometime before fall rains start. In this trial, all clippings made between June 1 and August 1 were effective in maintaining seed production and establishment. (2) If nitrogen fertilizer is used, apply $40 \mathrm{lbs}$. of $\mathrm{N} /$ acre in the spring on soils comparable to those in this study and remove by clipping or close grazing the heavy roughage at least once a year prior to September 1. (3) Although maximum yields of grass can be obtained by two clippings or grazings per season, at least three should be used on subclover. In this trial, maximum protein production resulted from 2-inch clippings made on May 1, June 1, and October 1, where no nitrogen fertilizer was added. (4) Grazing management and nitrogen fertilizer have only a slight effect in shifting the proportion of production to the early or late part of the growing season. In cases where the spring surplus cannot be used efficiently, carefully timed grazing or clipping sometime in May can be useful in improving the quality and acceptability of forage stored on the ground for use later in the summer. (5) These and other experimental data support the contentions that good subclover fertilization and management is essential to keep such a grass-legume mixture productive. Close grazing periodically, or clipping at a 2-inch stubble height, together with adequate phosphate fertilizer are essential ingredients in a management program designed to maintain good subclover-grass stands.

\section{Summary}

The influence of different clipping and fertilizing practices was studied over a 5-year period on an orchardgrass-subclover mixture near Corvallis, Oregon. Soils in the experimental area were moderately deep and fertile and represented a transition zone between the valley agricultural lands and typical hill pastures.

Climate of the area is a mild, sub-coastal type with moist, open winters and dry summers. Weather was reasonably constant during the trial with one crop year below average, two above and two about average.

An incomplete factorial design was used with a total of 42 treatments. These were completely randomized in four replications. Square-foot units were clipped from each plot in June of the first year and last year to calculate beginning and ending production and percent composition figures. Various combinations of five cutting dates were applied in four management systems throughout the three intervening years of the study, 1957 through 1959.

Significant results are as follows:

1. Response to phosphorus was marked but not for sulfur.

2. Highest yields were produced by 2-inch as compared with 3 -inch clipping heights and for only two rather than three cuts during the crop year.

3. Although both fall and spring nitrogen applications increased production, spring treatments were more effective and generally had less of a depressive influence on stands of subclover.

4. Spring applied nitrogen on the treatment cut October 1, May 1 and June 1 resulted in less increase than other treatments.

5. Amount of subclover and total yield were closely related. If plots were cut frequently and at a low stubble height, subclover was maintained even when 80 lbs. of $\mathrm{N}$ were applied annually.

6. No marked seasonal shifts in production were obtained by nitrogen applications of 80 lbs. of $\mathrm{N}$ per acre.

7. Crude protein percent and yields were higher on unfertilized plots and were related to the amount of subclover in the stand.

8. The application of these data to grazing management of perennial grasssubclover pastures was discussed. Close grazing periodically, or clipping at a 2-inch stubble height, together with adequate phosphate fertilizer, are essential ingredients in a management program designed to maintain good subclovergrass stands.

\section{LITERATURE CITED}

Alban, L. A. ANd M. Kellogg. 1959. Methods of soils analysis as used in the O.S.C. Soil Testing Laboratory. Misc. Paper 65:1-8.

ANDREW, W. D. 1960. The effect of varying row spacing and seeding density within rows of the perennial grass component of a mixed sward. Aust. Jour. Ag. Res. 2(5): 686-692.

Austenson, H. M. and H. G. Law. 1955. Effect of fertilizers on chemical composition of pasture herbage. Agronomy Abstracts. August 15.

Carpenter, E. J. and E. F. Torgerson. 1924. Soil survey of Benton County, Oregon. USDA Bureau of Soil Pub. 1431-1474.

Davis, R. R. AND D. S. BeLL. 1957. A comparison of birdsfoot trefoilbluegrass and ladino clover bluegrass for pasture: I. Response of lambs. Agron. Jour. 49:436-440.

HedRICK, D. W. AND GLEN HitchCock. 1953. Use of scythette in range forage studies. Jour. Range Mangt. $6: 182-184$.

McGuire, WILliam. 1961. Let bacteria "fix" subclover. Ore. Agric. Prog. Summer-Fall. 8(3-4):4-6.

WILlIAMS, W. A., R. M. Love AND L. J. BerRy. 1957. Production of range clovers. Calif. Agr. Expt. Sta. Cir. 458:1-19. 